\title{
Artificial Chinampas Soils of Mexico City: their Properties and Salinization Hazards
}

\author{
Suelos artificiales de chinampas de la Ciudad de México: propiedades y riesgos de \\ salinización \\ Solos artificiais da cidade do México - Chinampas: propriedades e riscos de salinização
}

\section{AUTHORS}

\section{Ramos Bello, R. ${ }^{1}$}

García Calderón, N.E. ${ }^{1}$

\section{Ortega Escobar,} H.M. ${ }^{2}$

Krasilnikov, $\mathbf{P}^{3 \oplus}$ pavel.krasilnikov@ gmail.com

@ Corresponding Author

${ }^{1}$ Facultad de Ciencias, UNAM, México.

2 COLPOS, Montecillo, Edo.de México.

${ }^{3}$ Institute of Biology KarRC RAS, 185910,

Pushkinskaya str., 11, Petrozavodsk, Russia.
Received: 24.03.2011 | Revised: 02.06.2011 | Accepted: 24.06.2011

\section{ABSTRACT}

The chinampas agriculture is a traditional land use practice in the Valley of Mexico since Pre-Hispanic time. The chinampas soils were constructed by excavation of lake sediments that resulted in the creation of a system of islands separated by channels. The agricultural productivity of these artificial soils was high; also the land use practices included forestry, fish breeding and hunting. Nowadays, the chinampas soils are affected by excessive salinity. We studied 10 representative soil profiles in the chinampas zone of Mexico City in order to characterize their properties and origin, to provide their classification, and to evaluate soil salinization, vertical distribution of the salts and their chemical composition. The soils are characterized by a layered structure, uniform dark grey colour, irregular vertical distribution of organic carbon and clay, and high percentage of carbon. Some soils show an increase in organic matter with depth, and other profiles have maximum organic matter content in the surficial layers and in the subsoil. The dynamics of sedimentation resulted in the decrease in organic matter in the upper layers of lacustrine sediments, because of recent increase in erosion rate and consequent increase in the proportion of mineral particles in the sediments. Most probably high organic matter content in surficial layers of some soils is due to excavation and accumulation of organic-rich subsoil material in the course of digging the channels. The concentration of soluble salts in superficial horizons, expressed as electric conductivity, varies in a wide range from 5 to almost 50 $\mathrm{dS} \cdot \mathrm{m}^{-1}$. The salts concentrate mainly in the superficial layers of soils. The abundance of the cations of soluble salts is $\mathrm{Na}^{+}>\mathrm{Mg}^{2+}>\mathrm{Ca}^{2+}>\mathrm{K}^{+}$and that of the anions is $\mathrm{SO}_{4}{ }^{2-}>\mathrm{Cl}^{-}>\mathrm{HCO}_{3}>\mathrm{CO}_{3}{ }^{2-}$. The alkaline reaction of soils is caused by exchangeable $\mathrm{Na}$ rather than by free sodium carbonates. The restoration of chinampas requires a complex approach, combining soil, water and ecosystems remediation.

\section{RESUMEN}

La agricultura de chinampas es una práctica tradicional de uso del suelo en el Valle de México desde la época prehispánica. Los suelos de chinampas fueron construidas por la excavación de sedimentos del lago que resultó en la creación de un sistema de islas separadas por canales. La productividad agricola de estos suelos artificiales fue alta; también las prácticas de uso del suelo incluyeron la silvicultura, la pesca y la caza. Actualmente, los suelos de chinampas están afectados por una salinidad excesiva. Se estudiaron 10 perfiles de suelos representativos de la zona de chinampas de la Ciudad de México con el objeto de caracterizar sus propiedades y origen, obtener su clasificación, evaluar la salinización del suelo, la distribución vertical de las sales y su composición quimica. Los suelos se caracte-rizan por presentar una estructura en capas, de color gris oscuro uniforme, y una irregular distribución vertical de carbono orgánico y arcilla. Algunos suelos muestran un aumento de la materia orgánica con la profundidad y otros perfiles presentan un contenido alto de esta en las capas superficiales y en el subsuelo. La dinámica de 
la sedimentación como resultado de la disminución de la materia orgánica en las capas superiores de los sedimentos lacustres se debe al aumento reciente en la tasa de erosión y al consiguiente aumento en la proporción de particulas minerales en los sedimentos. El alto contenido de materia orgánica en las capas superficiales de algunos suelos se debe a la acumulación de material del subsuelo rico en materia orgánica obtenida del fondo de los canales. La concentración de sales solubles en los horizontes superficiales, expresada como conductividad eléctrica, varía de 5 a 50 $d S \cdot m^{-1}$. Las sales se concentran principalmente en las capas superficiales de los suelos. La abundancia de los cationes de las sales solubles es $\mathrm{Na}^{+}>\mathrm{Mg}^{2+}>\mathrm{Ca}^{2+}>\mathrm{K}^{+}$y la de los aniones es $\mathrm{SO}_{4}^{2-}>\mathrm{Cl}^{-}>\mathrm{HCO}_{3}^{-}>\mathrm{CO}_{3}^{2-}$. La reacción alcalina de los suelos se debe al $\mathrm{Na}^{+}$intercambiable más que por carbonatos de sodio libres. La recuperación de las chinampas requiere de un planteamiento complejo, con la combinación del suelo, agua y de la recuperación de los ecosistemas.

\section{RESUMO}

A agricultura de Chinampas é uma prática tradicional do uso do solo no Vale do México, desde tempos pré-hispânicos. Os solos de Chinampas foram construídos em consequência da escavação de sedimentos lacustres, resultando na criação de um sistema de ilhas separadas por canais. A produtividade agricola desses solos artificiais era elevada bem como as práticas de uso do solo incluindo pesca, silvicultura e caça. Estes solos caracterizam-se por uma estrutura em camadas, de cor cinza escuro uniforme, e uma distribuição vertical irregular de carbono orgânico e argila. Alguns solos apresentam um aumento da matéria orgânica com a profundidade enquanto outros apresentam perfis com um alto teor de matéria orgânica nas camadas superficiais e subsolo. A dinâmica de sedimentação como resultado da diminuição de matéria orgânica nas camadas superiores dos sedimentos lacustres deve-se ao recente aumento da taxa de erosão e ao consequente aumento da proporção de partículas minerais nos sedimentos. Este alto teor de matéria orgânica nas camadas superficiais de alguns solos deve-se à acumulação de material do subsolo rico em matéria orgânica com origem no fundo dos canais. A concentração de sais solúveis nos horizontes de superfície, expressa pela condutividade eléctrica varia de 5-50 dS $\mathrm{m}^{-1}$. Os sais concentram-se principalmente nas camadas superficiais do solo. A abundância de catióes de sais solúveis segue a seguinte ordem: $\mathrm{Na}^{+}>\mathrm{Mg}^{2+}>\mathrm{Ca}^{2+}>\mathrm{K}^{+}$e a dos aniôes a ordem: $\mathrm{SO}_{4}{ }_{4}^{2-}>\mathrm{Cl}^{-}>\mathrm{HCO}_{3}{ }^{-}>\mathrm{CO}_{3}{ }^{2-}$. A reacção alcalina dos solos deve-se sobretudo ao sódio de troca e não ao carbonato de sódio de troca livre. A recuperação das chinampas exige uma abordagem complexa, que combina a remediação do solo, água e ecossistemas.

KEYWORDS artificial soils, Anthrosols, soluble salts, lacustrine sediments, pyroclastic sediments

PALABRAS

CLAVE

suelos artificiales, Anthrosoles, sales solubles, sedimentos lacustres, sedimentos piroclásticos

PALAVRAS-

CHAVE

Solos artificiais, Antrossolos, sais solúveis, sedimentos lacustres, sedimentos piroclásticos 


\section{Introduction}

Chinampas are agroecosystems developed in the lacustrine zone of the catchment of Mexico in periodically flooded or shallow areas. The beginning of chinampas agriculture is referred to the Classical period of Pre-Hispanic culture in Mesoamerica, to the beginning of $11^{\text {th }}$ century P.C. (Rojas-Rabiela 1983). These areas were used by small ethnic groups such as chichimeca, acolhua, tepaneca, otomi, some groups influenced by Toltec culture, and, later, dominated by Aztecs. These groups developed a specific culture and technology: irrigation by flooding, and formation of a series of elevated fields for agricultural production (Ezcurra 1990). Chinampas (a word of nahuatl origin: chinamitl - "straw bed", and pan - "over") are portions of soil material designed for capturing water. The fields were made by accumulation of organic matter, loamy lacustrine sediments, or any material which served to consolidate the islands, separated by a system of channels, which served for communication and drainage (Jiménez et al. 1995). The soil surface is about one meter over the water level. In the course of chinampas use, additional lake mud could be added, or excessive soils could be removed to construct new chinampas (Coe 1964).

The system of chinampas is a traditional agrarian technique, which includes a series of agronomic, fishery, and forestry activities (GómezPompa 1978; Ezcurra 1990; Rosas et al. 1984). Crop production, at least of 30 species, including maize, vegetables and other eatable crops, provided high diversity of the agroecosystem and balanced nutrition for the producers (West and Armillas 1950; Rojas-Rabiela 1990). The chinampas zone of Xochimilco was characterized by a combination of growing vegetables and flowers that favored biological diversity and economic sustainability of the region. Moreover, most cultivated fields were combined with fruit trees and some forest trees, such as Salix bonplandiana and Schinus mole, which stabilizes the soil. Another activity developed in the system was fishery and collection of various organisms: birds, water invertebrates, rabbits, frogs, etc., which formed a significant part of the diet of the producers (Rojas-Rabiela 1983).
An important component of the agroecosystem is the net of channels, which have been used as a drainage system, as well as for irrigation and maintaining soil humidity. Excessive use of the water of the channels resulted in the lowering of water level, drying and almost disappearance of the lake. Recently, since 1959, the water level has been improved with the use of wastewater. The wastewater has high concentration of salts, toxic metals and pathogenic organisms, which affect the soil, animals, and vegetation; moreover, it is a serious problem for public health (Rosas et al. 1984; Vallejo and Aguilera 1994). The concentration of salts in the water is the most dangerous issue: for example, sodium concentrations in the main channels are regularly found to be $0.5 \mathrm{~g}$ per liter which hurts aquatic plants and causes soil salinization (Lot et al. 1979).

Surprisingly, the soils of chinampas have not received much attention in scientific literature. Though numerous studies have been conducted in Mexico, their results mostly appeared as thesis of various levels or conference abstracts, i.e. in a form practically unavailable for scientific community. Few papers published in scientific journals dealt with particular issues, such as chinampas cultural heritage (Rojas-Rebela 1983), organic matter composition (García et al. 1994; Reyes-Ortigoza and García-Calderón 2004; González-Salgado et al. 2010), contamination (Vallejo 1994; Ramos-Bello 2001) or microbiology (Rosas 1984). Until now the morphology and properties of chinampas soils have not been reported in internationally available papers. The need for an adequate characterization of these unique soils is redoubled because the whole chinampas system is endangered due to increasing urbanization and contamination of the area. It is important to know reference characteristics of chinampas soils and to estimate the salinization risks in order to develop efficient management, protection and improvement techniques.

The objective of our study was to characterize the morphology and properties of chinampas soils of Mexico City, to evaluate their actual salinity and to estimate the potential salinization of these soils. 


\section{Study sites}

The district of Xochimilco is located at $88^{\circ} 09^{\prime} 04^{\prime \prime}$ and $87^{\circ} 99^{\prime} 00^{\prime \prime}$ West longitude and 19¹7'35" and $19^{\circ} 08^{\prime} 57^{\prime \prime}$ North latitude; the medium altitude of the site is $2,240 \mathrm{~m}$ above sea level. The community is formed by 14 villages, among which Santa María Nativitas, Santa Cruz Acalpixca, San Gregorio Atlapulco, San Luís Tlaxialtemalco, Santiago Tulyehualco and Xochimilco are "chinamperos", i.e. are constructed on excavated lacustrine sediments, dissected by channels. Xochimilco is situated in the hydrological region Chalco-Xochimilco, which is a part of the catchment of Mexico. This catchment occupies an area of 21,000 ha, where about 800 ha are not used for agriculture at the present time.

The climatic conditions, according to the system of Köppen, modified by García (1973), are classified as temperate subhumid with summer rainfalls, with a medium annual temperature between 12 and $18^{\circ} \mathrm{C}$, the temperature of the coldest month varying from -3 to $18^{\circ} \mathrm{C}$, and the temperature of the hottest month less than $22^{\circ} \mathrm{C}$. Medium annual precipitation varies from 680 to $936 \mathrm{~mm}$, with the most rainy months from June to September, and the driest period from November to March (INEGI 1997).

Xochimilco is surrounded by a chain of mountains, the most important being Sierra de Guadalupe, Sierra Chichinautzin, Cuautzin, and
Sierra de Patlachique in the south, Sierra Nevada in the east, and Sierra de Las Cruces in the west. According to the geological data, the zone is composed mainly of alluvial materials, derived from Sierra Nevada and Sierra de Las Cruces. Also, there are materials originated from the last periods of volcanic activities, such as basalts and pyroclastic materials.

The lake of Xochimilco has an irregular form, stretching from east to west, and is more than $11 \mathrm{~km}$ in length and $2 \mathrm{~km}$ in breadth, with a total area of 2,200 ha. It consists of a system of channels; the most important are Cuemanco, Nacional, Caltongo, San Cristobal, el Bordo, Japón, Apatlaco, Tlicuili, and Tlilac.

We studied 10 soil profiles, concentrated in four sites, corresponding to the main chinampas zones in Mexico City (Figure 1; Table 1). The soil pits were located in the sites of Xochimilco (Profiles 1 and 2), San Luís Tlaxialtemalco (Profiles 3, 4, and 5), Tláhuac (Profiles 6, 7, and 8), and Míxquic (Profiles 9 and 10). The depth of the profiles varied between 90 and $180 \mathrm{~cm}$ depending on the water table. The sampling was done during winter and spring which correspond to the dry season. Since the profiles were difficult for division into genetic horizons, the morphological description and soil sampling were done every $10 \mathrm{~cm}$ down to the groundwater level.

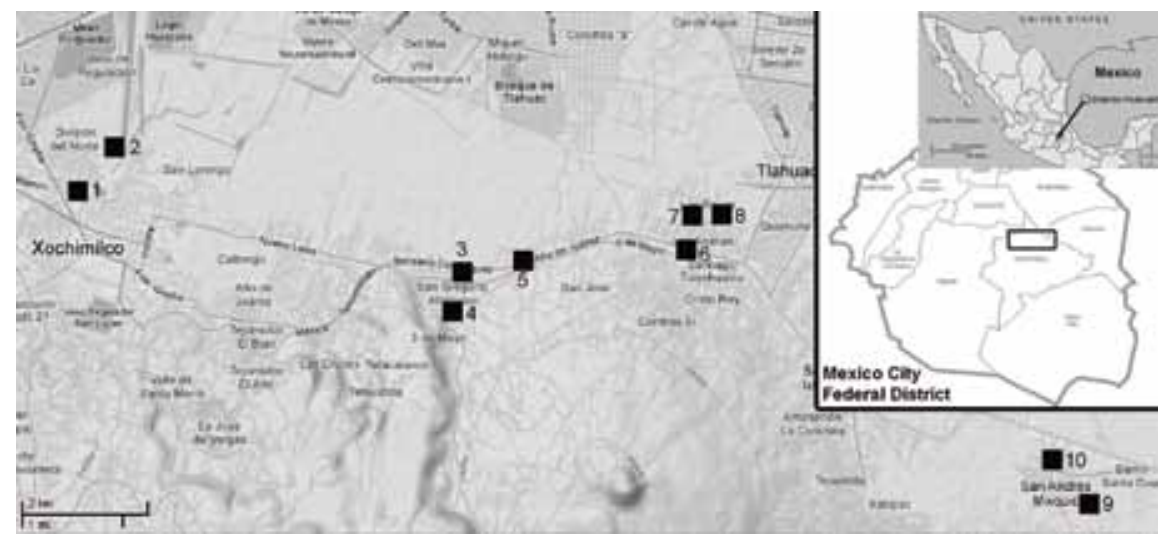

Figure 1. Schematic map of the study area in the chinampas area of Mexico City. Black boxes correspond to soil profiles. 
Table 1. The location of soil profiles in chinampas zone of Mexico City

\begin{tabular}{|c|c|c|c|}
\hline No. profile & Coordinates & & Locality \\
\hline 1 & $19^{\circ} 16^{\prime} 9.7 " \mathrm{~N}$ & $99^{\circ} 05^{\prime} 16.1 " \mathrm{~W}$ & Xochimilco \\
\hline 2 & $19^{\circ} 16^{\prime} 46.5^{\prime \prime} \mathrm{N}$ & 9905'17.3" W & Xochimilco \\
\hline 3 & $19^{\circ} 1545.7 ” \mathrm{~N}$ & $99^{\circ} 02^{\prime} 4.4^{\prime \prime} \mathrm{W}$ & San Luís Tlaxialtemalco \\
\hline 4 & $19^{\circ} 15^{\prime} 33.2 " N$ & $99^{\circ} 02^{\prime} 5.2^{\prime \prime} \mathrm{W}$ & San Luís Tlaxialtemalco \\
\hline 5 & $19^{\circ} 15^{\prime} 46.5^{\prime \prime} \mathrm{N}$ & $99^{\circ} 01^{\prime} 55.3^{\prime \prime} \mathrm{W}$ & San Luís Tlaxialtemalco \\
\hline 6 & $19^{\circ} 15^{\prime} 58.4 " N$ & $99^{\circ} 00^{\prime} 23.1^{\prime \prime} \mathrm{W}$ & Tláhuac \\
\hline 7 & $19^{\circ} 16^{\prime} 3.8^{\prime \prime} \mathrm{N}$ & $99^{\circ} 00^{\prime} 33.9^{\prime \prime} \mathrm{W}$ & Tláhuac \\
\hline 8 & $19^{\circ} 16^{\prime} 5.6 ” N$ & $99^{\circ} 00^{\prime} 20^{\prime \prime} \mathrm{W}$ & Tláhuac \\
\hline 9 & $19^{\circ} 13^{\prime} 13.8^{\prime \prime} \mathrm{N}$ & $98^{\circ} 57^{\prime} 29.3^{\prime \prime} \mathrm{W}$ & Míxquic \\
\hline 10 & $19^{\circ} 13^{\prime} 17.8^{\prime \prime} \mathrm{N}$ & $98^{\circ} 57^{\prime} 28.3^{\prime \prime} \mathrm{W}$ & Míxquic \\
\hline
\end{tabular}

\section{Methods}

Morphological description was done according to Schoeneberger et al. (2002). Colour was identified using Munsell Soil Color Charts (2000). The description was made by soil horizons, though only a provisional division into genetic horizons could be done. The chinampas soils generally have a homogeneous dark-coloured profile, with minor variation in organic matter content and texture which are difficult to distinguish in the field. Since soil horizons were difficult to discern, we collected samples for chemical analysis every $10 \mathrm{~cm}$ down to the groundwater level. The samples were analyzed according to the routine methods of soil chemical and physical analysis (van Reeuwijk 2002; Burt 2004). In each sample we determined: $\mathrm{pH}$ with a glass electrode-calomel electrode $\mathrm{pH}$ meter method $\left(\mathrm{H}_{2} \mathrm{O}\right.$ and $1 \mathrm{MKCl}$ extraction with a soil: solution ratio 1:2.5), organic $\mathrm{C}$ by wet combustion, exchangeable bases by $\mathrm{NH}_{4} \mathrm{Ac}$ method, and cation exchange capacity (CEC) by calcium chloride saturation. Soluble salts were washed out with alcohol before exchangeable bases extraction and CEC evalua- tion. The bulk density was determined using the cylinder method, and the texture using the hydrometer method (Tan 1996). The electric conductivity and ionic composition were evaluated in saturated paste (Jackson 1969), the ionic concentrations of $\mathrm{Ca}^{2+}$ and $\mathrm{Mg}^{2+}$ were measured by atomic adsorption spectrometer, $\mathrm{K}^{+}$and $\mathrm{Na}^{+}$by flame photometer, chlorites by precipitation with silver nitrate and potassium dichromate indicator, sulphates - gravimetrically, carbonates and bicarbonates - volumetrically. Soils were classified according to the World Reference Base (IUSS Working Group WRB 2006). 


\section{Results}

\section{Soil morphology and properties}

The morphological characteristics of all the studied profiles were similar. All the soils had a relatively uniform profile down to $120-160 \mathrm{~cm}$. The division into horizons might be done mainly by slight differences in organic matter content and texture. Since distinguishing horizons was difficult and it was not clear whether this discrepancy was a result of pedogenetic processes or lithological discontinuity, we preferred describing the soil by $10-\mathrm{cm}$ layers. In general terms, the morphology of the chinampas soils resembled that of deep organic soils (Histosols), but the organic matter content was lower. The colour of the profiles was black when moist (10YR 2/1), and varied from grey (10YR 5/1) to dark grey (10YR 4/1) when dry. The texture varied from silty loam to clay, and in deeper layers of most of the profiles the texture seemed to be heavier than in the topsoil layers. All the layers were soft and friable. The structure was weak subangular blocky. At more than $1 \mathrm{~m}$ depth some profiles had a thin light-grey layer that has been previously reported to be a diatomic shells accumulation (Reyes-Ortigoza and García-Calderón 2004). The presence of such layers identified undisturbed lacustrine sediments. During the dry season the surficial layers down to $30-50 \mathrm{~cm}$ were dry or slightly moist, and the deeper soil horizons were moist and wet, with moisture contents increasing with depth. Though soils were saturated with water, dark organic matter did not permit observing gleycolours. Iron depletion was not observed in these soils, because Fe did not reduce in alkaline environments even when RedOx potential was low. Manganese depletion was possible, but it was difficult to detect in black matrix. Some profiles of the sites San Luís Tlaxialtemalco (profile 3), Tláhuac (profile 8) and the profiles of Míxquichad efflorescences of soluble salts in overdried surficial horizons.

The bulk density was very low in all the profiles (Figure 2), with maximum values in the topsoil less than $0.8 \mathrm{~g} \bullet \mathrm{kg}^{-1}$. At the sites Xochimilco, San Luís Tlaxialtemalco and Tláhuac the bulk density decreased with depth irregularly; at the site Míxquic the decrease was strong and continuous. At the latter site the soils showed the lowest bulk density values, which in deeper layers corresponded to the values reported for organic soils $\left(0.2-0.4 \mathrm{~g} \mathrm{~kg}^{-1}\right)$.
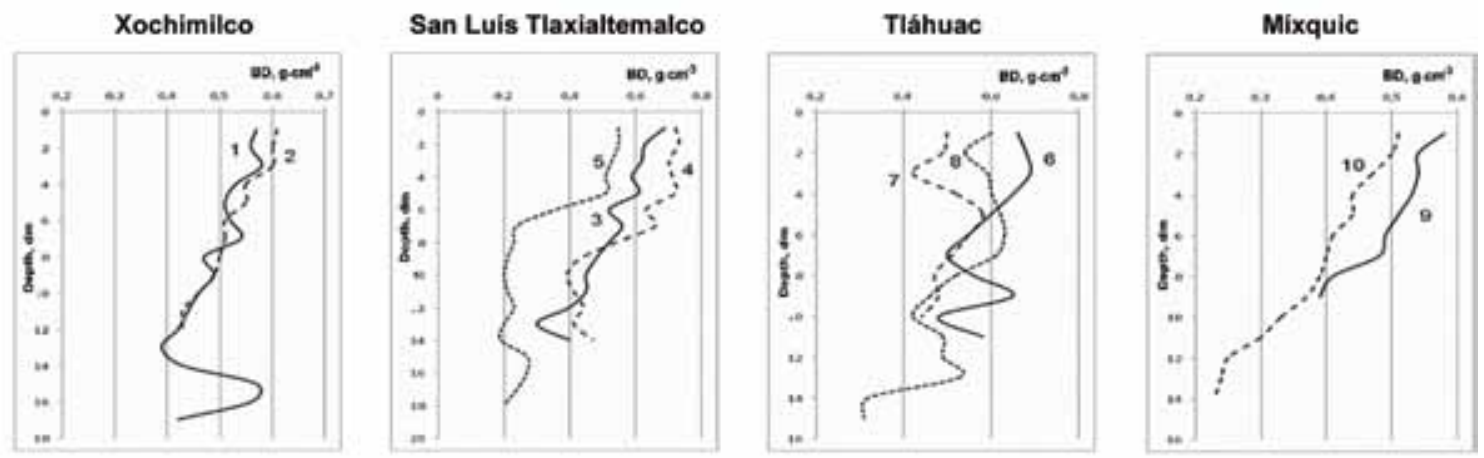

Figure 2. Bulk density of the "chinampas* soils: numbers of the curves correspond to the profile numbers. 
The organic $\mathrm{C}$ content strongly varied between the sites and between the layers in the same profile (Figure 3). In the surficial layer (more or less the upper $50 \mathrm{~cm}$ ) the organic $\mathrm{C}$ concentration was around $10 \%$ at the sites Xochimilco and Míxquic, and about $5 \%$ at the sites San Luís Tlaxialtemalco and Tláhuac. The vertical distribution of organic $\mathrm{C}$ showed two principal patterns: in the profiles of the sites San Luís Tlaxialtemalco and Tláhuac its content was relatively uniform or increased with depth, and in the profiles of Xochimilco and Míxquic it showed a bimodal distribution with maximum values in the topsoil and at more than $1 \mathrm{~m}$ depth.

Clay content differed between the profiles in a wide range, from $5 \%$ to almost $80 \%$ among the profiles, even in those located at the same site (Figure 4). The vertical distribution of clay was strongly irregular in almost all the profiles. Only the profiles of the site Míxquic showed anunimodal distribution of clay with maximum values at depths between 20 and $100 \mathrm{~cm}$.
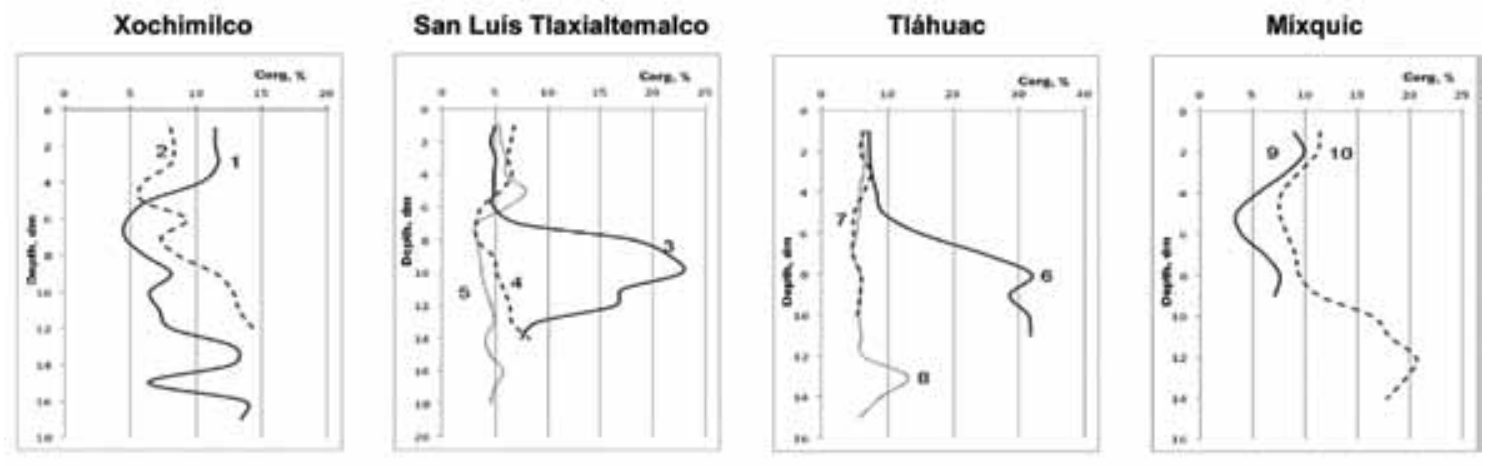

Figure 3. Organic carbon concentration in the *chinampas* soils: numbers of the curves correspond to the profile numbers.
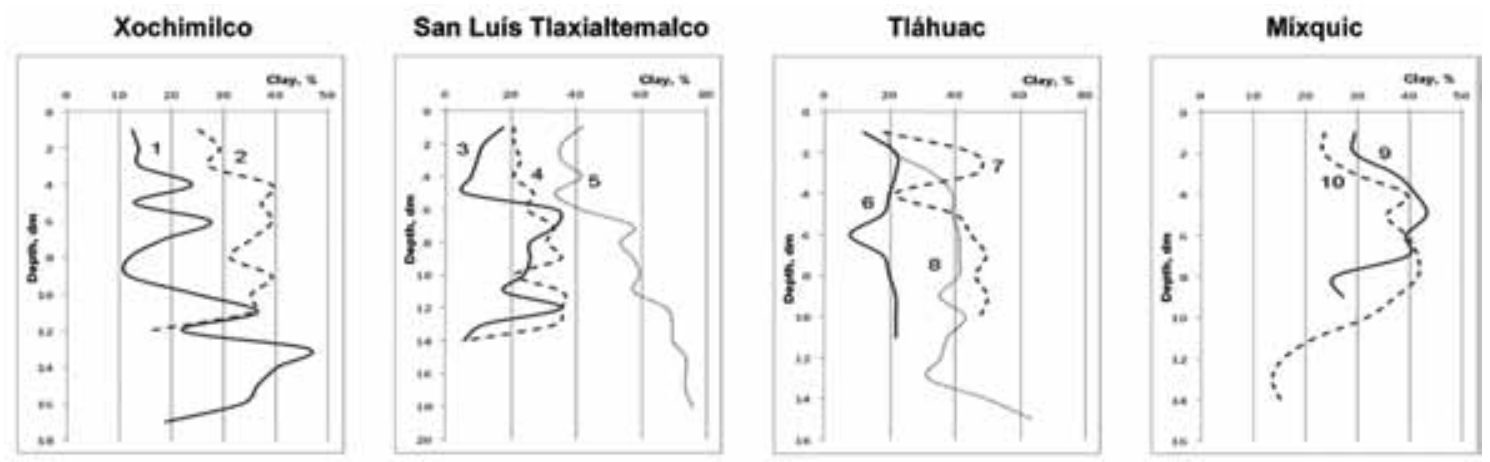

Figure 4. Clay content in the ${ }^{*}$ chinampas ${ }^{*}$ soils: numbers of the curves correspond to the profile numbers. 
The reaction of the surficial layers of all the soils profiles was alkaline, with $\mathrm{pH}$ values around 8.5 (Figure 5). In all the profiles the $\mathrm{pH}$ values decreased with depth. In two profiles, No. 2 (Xochimilco) and 10 (Míxquic) the $\mathrm{pH}$ values dropped down at the depth of $100-120 \mathrm{~cm}$ to values lower than 6 that meant slightly acid reaction. In some profiles the $\mathrm{pH}$ values increased slightly with depth down to $50-100 \mathrm{~cm}$; in the profiles 1 (Xochimilco) and 8 (Tláhuac) the $\mathrm{pH}$ exceeded 9. Even lower the $\mathrm{pH}$ values also decreased in these profiles.

\section{Soil salinity and sodicity}

Soil salinity data, expressed as electric conductivity $(\mathrm{EC})$, showed that all the profiles were characterized by elevated salt contents (Figure 6). However, only several profiles had a soluble salt concentration that is recognized as severe salinity according to US Salinity Laboratory Staff (1954) $\left(E C>16 \mathrm{dS} \bullet \mathrm{m}^{-1}\right)$ or considered as a salic horizon (IUSS Working Group WRB, 2006) (EC > $15 \mathrm{dS} \bullet \mathrm{m}^{-1}$ ). Four profiles, No. 3 (San LuísTlaxialtemalco), 8 (Tláhuac), 9, and 10 (Míxquic) had a strongly expressed accumulation of soluble salts in the topsoil layer. In the profiles 3 and 8 the conductivity was as high as $45-50 \mathrm{dS} \bullet \mathrm{m}^{-1}$. It should be mentioned that for alkaline soils with $\mathrm{pH}$ higher than 8.5 the criteria for salic horizon (IUSS Working Group WRB 2006) are broader $\left(E C>8 \mathrm{dS} \bullet \mathrm{m}^{-1}\right)$, because alkaline reaction implies the presence of sodium carbonates that are considered to be more toxic than other salts. According to this criterion, all the soils, except for those of the Xochimilco site, should be considered to be severely saline. It was remarkable that within the same site the difference in soluble salts concentration in the surficial horizon was great. The vertical distribution of salts also varied between the profiles. Most profiles showed an accumulative pattern with an intensive maximum at the surface and a sharp decrease with depth, like the profiles mentioned above for high salinity. In the profiles 4, 5 (San Luís Tlaxialtemalco), 6 , and 7 (Tláhuac) the salinity decreased gradually with depth. Profiles 1 and 2 (Xochimilco) showed an irregular vertical distribution of soluble salts.

Soil sodicity could be expected already from high $\mathrm{pH}$ values (Figure 5). However, alkaline reaction could be caused either by the presence of sodium carbonates or exchangeable sodium; in most soils both mechanisms might be used for explanation (Gutiérrez et al. 1995; Sánchez et al. 2003). The data of the percentage of sodium saturation (PSS) of the exchangeable complex of the soils are presented in Figure 7. All the profiles had values higher than a critical value of $15 \%$ of sodium saturation (US Salinity Laboratory Staff 1954) within the first $50 \mathrm{~cm}$, except for the profiles 2 (Xochimilco) and 4 (San Luís Tlaxialtemalco). The vertical distribution of PSS values was mostly irregular.
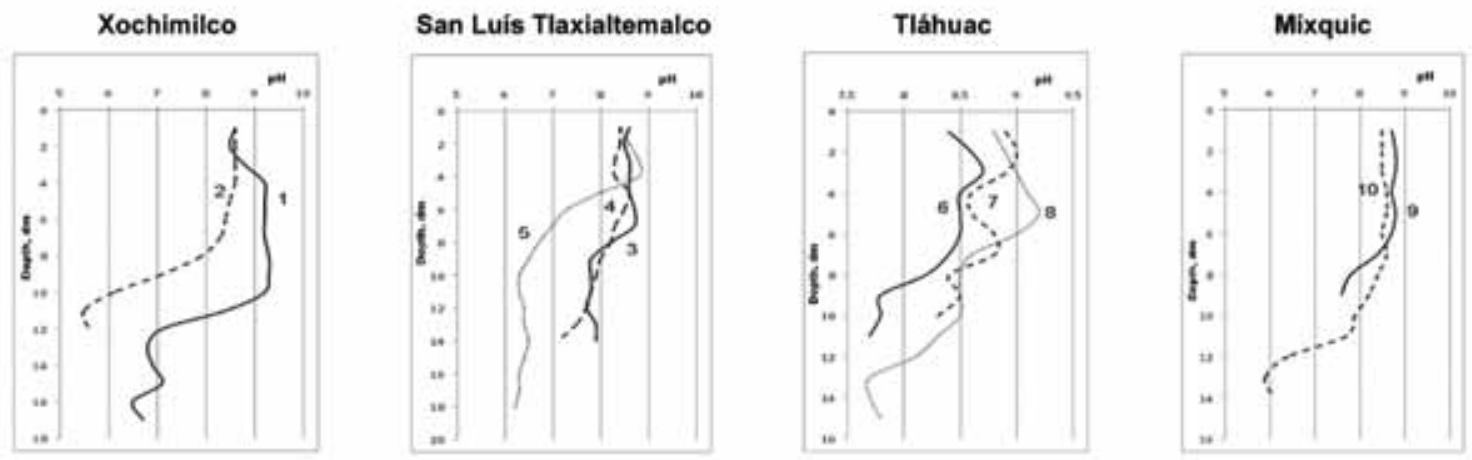

Figure 5. The $\mathrm{pH}$ values of the *chinampas* soils: numbers of the curves correspond to the profile numbers. 

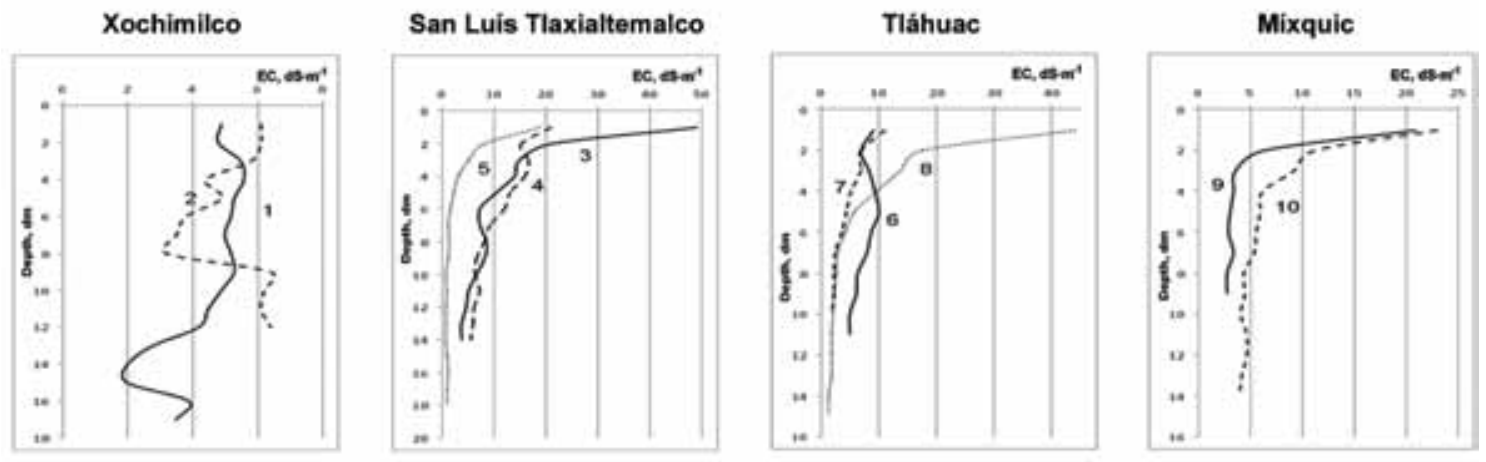

Figure 6. Electric conductivity of the *chinampas ${ }^{*}$ soils: numbers of the curves correspond to the profile numbers.
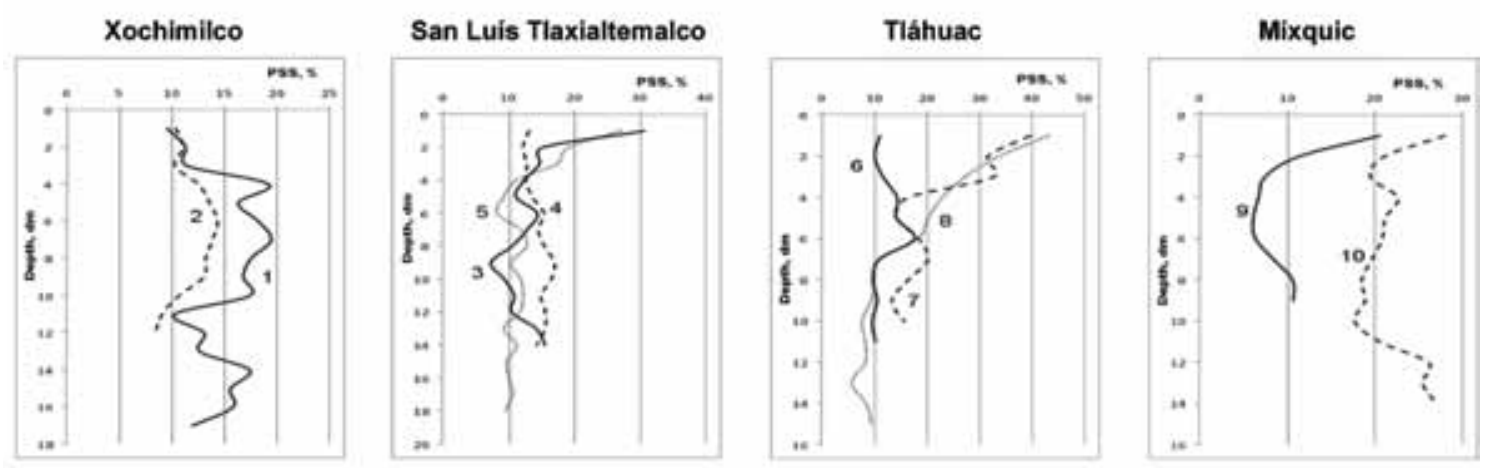

Figure 7. Percentage of sodium saturation of the ${ }^{*}$ chinampas* soils: numbers of the curves correspond to the profile numbers.

The composition of soluble salts is shown in Figure 8; only one profile per site was pictured, because the distributions were similar among the profiles of the same site. At the Xochimilco site, the total concentration of ions of the saturated paste in the profile had a bimodal distribution, with maximum values in the topsoil and at more than $1 \mathrm{~m}$ depth. The topsoil had a cation concentration sequence $\mathrm{Na}^{+}>\mathrm{Mg}^{2+}>\mathrm{Ca}^{2+}$, and $\mathrm{Ca}^{2+}$ concentration increased with depth, while $\mathrm{Na}^{+}$and $\mathrm{Mg}^{2+}$ concentrations slightly decreased. The concentration of $\mathrm{K}^{+}$was negligible through- out the profile. In the anionic part, the topsoil had the following sequence of concentrations: $\mathrm{SO}_{4}{ }^{2-}>\mathrm{Cl}>\mathrm{HCO}_{3}>\mathrm{CO}_{3}{ }^{2-}$. With depth, the concentration of sulphates strongly increased, and that of bicarbonates decreased; the carbonates were not present in the subsoil at all, and chlorides concentration remained the same. At the site San Luís Tlaxialtemalco the soils had the highest ionic concentration in the surficial layer; the concentration sharply decreased with depth. The abundance of cations had the same sequence as for Xochimilco profiles, but the con- 


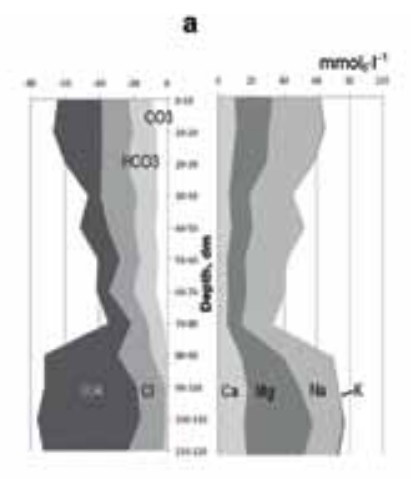

b

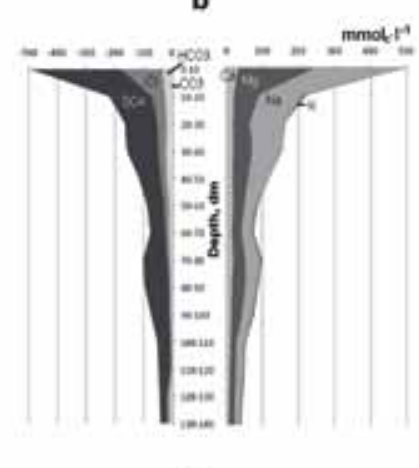

c

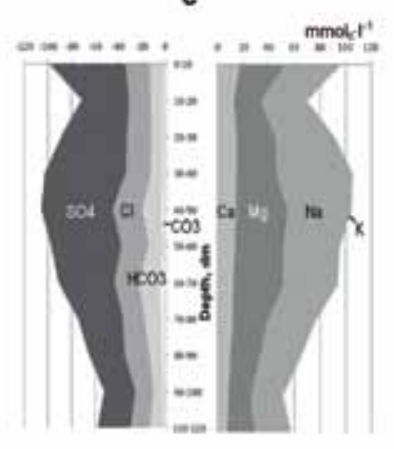

d

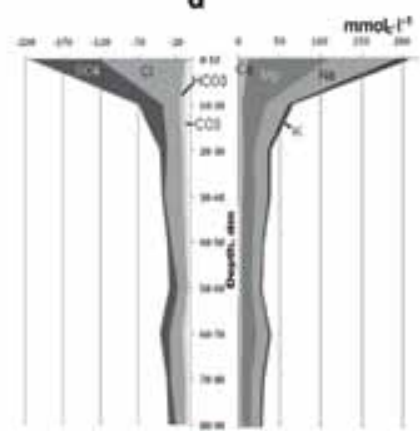

Figure 8. Ionic composition of the saturated paste of selected *chinampas*soils:

${ }^{*} \mathrm{a}^{*}$ - profile 2, Xochimilco site, ${ }^{*} \mathrm{~b}^{*}-$ profile 4 , San Luís Tlaxialtemalco, ${ }^{*} \mathrm{c}^{\star}$ - profile 6 , Tláhuac site, and ${ }^{*} \mathrm{~d}^{*}$ - profile 9, Mixquic site. See text for details. centrations of $\mathrm{Na}^{+}$and $\mathrm{Mg}^{2+}$ were much higher than that of $\mathrm{Ca}^{2+}$ at all depths. In the anionic part, also $\mathrm{HCO}_{3}{ }^{-}$and $\mathrm{CO}_{3}{ }^{2-}$ concentrations were negligible compared with that of $\mathrm{SO}_{4}{ }^{2-}$ and $\mathrm{Cl}^{-}$. At the Tláhuac site, the profiles had a distribution of total ionic concentration with two humps: in the surficial layer and at the depth of 40-50 $\mathrm{cm}$. The most abundant cations were $\mathrm{Na}^{+}$and $\mathrm{Mg}^{2+}$; the ratio between these two cations varied with depth, while $\mathrm{Ca}^{2+}$ concentration was almost uniform. Among the anions, the most abundant was sulphate, its concentration varying with depth, while chloride and bicarbonate concentrations were relatively uniform. The carbonate and potassium ionic concentrations were low. The profiles of the Míxquic site had a pattern of distribution of the ions in the saturated paste similar to that in the soils of the site San Luís Tlaxialtemalco. The difference was that at the Míxquic site the concentration of $\mathrm{Mg}^{2+}$ was slightly higher than that of $\mathrm{Na}^{+}$, chlorides were more abundant than sulphates, and $\mathrm{K}^{+}$concentration was higher than in the soils of other sites. 


\section{Discussion}

\section{The origin and classification of soils}

The parent material of all the studied soils consists of lacustrine sediments, disturbed by human activities. All the soils are characterized by non-uniform vertical distribution of the texture and some other properties, such as organic matter content, bulk density, etc. The main question to answer is: the heterogeneity of texture and related soil properties is a result of lithological discontinuity, human disturbance, or pedogenetic processes? We believe that pedogenetic hypothesis should be disregarded for several reasons. First, such a strong clay translocation requires long time and stable environments (Birkeland 1999; Targulian and Krasilnikov 2007), while chinampas are known to be exposed to the surface not very long ago, and the landscape has undergone many changes in hydrological regime and microclimatic conditions since the expose (De Cserna et al. 1988). Secondly, the mineral part of soil clays in chinampas consists mainly of poorly ordered products of initial weathering of volcanic ashes (Huez et al. 1989); these components are known to be hardly mobile in soils (Sedov et al. 2003). Finally, the vertical distribution of clay content is different in soils at different sites: it is difficult to expect that the pedogenetic processes would act so differently at short distances under almost the same environments. Non-uniformity of lacustrine sedimentation was reported for the lakes of the Valley of Mexico (e.g. Bradbury 1971), thus the irregular vertical distribution of clay content in chinampas soils might be also ascribed to the historical fluctuations in sedimentation rates. For better understanding of the origin of the soils of chinampas we also interpreted the vertical distribution of organic matter content in the soils. The organic matter concentration increases with depth in soils at the sites San Luís Tlaxialtemalco and Tláhuac. This type of distribution corresponds well with the sedimentation history of the region. According to the paleogeographical reconstructions, the Valley of Mexico was covered with forest vegetation, but in the historical time the aridization of climate and human invasion resulted in almost complete deforestation of the area (Heine 1987). The loss of vegetation and intensive cultivation has led to intensive soil erosion, thus increasing the ratio of mineral particles in lacustrine sediments. Consequently, the recent upper layers of lake deposits have higher proportion of mineral particles and lower percentage of organic carbon. However, at the other two sites (Xochimilco and Míxquic) the soils have two maximums of organic carbon concentration in the subsoil and in the surficial layer. If we accept the hypothesis of recent increase in mineral material sedimentation due to human-induced erosion, the increase in soil organic matter in surficial layer should be specially explained. The increase in organic matter might be ascribed to accumulation of the organic-rich materials, raised in the course of excavation of channels. The other possibility is that strong accumulation of organic matter was due to manuring and warping (González-Salgado et al. 2010). Finally, natural accumulation of organic matter in the topsoil may be ascribed to a natural humification process under grass vegetation (García et al. 1994; Reyes-Ortigoza and GarcíaCalderón 2004). The latter hypothesis is not very convincing because the vegetation is practically the same at all the studied sites, and it is difficult to explain why the vertical distribution is completely different under the same natural conditions. The contribution of excavated material versus manure addition is still under question; the similarities in organic matter composition among the upper and deep soil layers reported by Reyes-Ortigoza and García-Calderón (2004) allow giving a priority to the suggestion that the organic matter in the topsoil comes from deeper lacustrine sediments. However, further studies are needed to confirm this hypothesis.

The classification of the soils under study was unclear until recently. The first round of soil survey made by INEGI (1997) showed the chinampas soils of metropolitan areas as Phaeozems, i.e. mineral soils with deep humus-rich surficial horizon, with high base saturation throughout the profile and no secondary carbonates (IUSS Working Group WRB 2006). The name was given using the earlier version of the international soil classification (CETENAL 1970), where anthropogenically transformed soils were absent. The disadvantage of this classification was that the anthropogenic transformation of the soil, the layering of soil-forming material, the presence of 
organic layers and salt accumulations were not reflected. Recently, soil research and mapping in Mexico accepted the latest version of the World Reference Base for Soil Resources (IUSS Working Group WRB 2006). The experts who developed this classification visited Mexico, including the chinampas area, and provided a correct classification name for these soils: Terric Anthrosols (Reyes-Ortigoza and García-Calderón 2004). The name means that the soils formed under continuous intensive agricultural use with an addition of mineral and organic materials on the surface. For additional characteristics of these soils, other prefix and suffix modifiers may be added (Table 2). All the studied profiles receive also a prefix qualifier Fluvic, because they have fluvic materials, evidenced by irregular vertical distribution of clay and organic carbon content (Figures 3 and 4). The soils of the sites San Luís Tlaxialtemalco and Míxquic also have a prefix modifier Episalic that means that there are salic horizons in the upper $50 \mathrm{~cm}$ of these profiles, i.e. the electric conductivity is more than $15 \mathrm{dS} \bullet \mathrm{m}^{-1}\left(>8 \mathrm{dS} \bullet \mathrm{m}^{-1}\right.$ in the case of alkaline soils) in the surficial layer. Almost all the profiles except for one soil at the Xochimilco site also have the suffix modifier Sodic that means that the PSS is higher than $15 \%$ in the upper $50 \mathrm{~cm}$ of the soils; in some cases the suffix Endosodic is used to show that the PSS $>15 \%$ is found at the depth 50-100 cm, or Hypododic if the PSS > $15 \%$ is found only in a thin surficial layer, but the profile has PSS $>6 \%$ throughout. About half of the soils also received a suffix modifier Alcalic, which means that the soil has $\mathrm{pH}>8.5$ in the upper $50 \mathrm{~cm}$ of the profile. Three soils have organic materials in the profile, and receive suffix modifiers Thaptohistic, if the organic material is found between 50 and $100 \mathrm{~cm}$, or Bathihistic, if the organic material is located at more than 100 $\mathrm{cm}$ depth. Finally, some soils having layers of clayey texture received a suffix Clayic; if the layer is found between 50 and $100 \mathrm{~cm}$, the modifier is used in the form Endoclayic. Summarizing, the use of the latest version of the international classification (IUSS Working Group WRB 2006) adequately reflects the origin of chinampas soils and allows including practically all the details of particular soil properties. Also it reflects the internal variation in soil properties in the chinampas zone.

Table 2. The classification of soil profiles in chinampas zone of Mexico City (IUSS Working Group WRB 2006)

\begin{tabular}{lll} 
No. profile & Locality & Classification \\
\hline 1 & Xochimilco & Fluvic Terric Anthrosol (Endosodic, Alcalic) \\
\hline 2 & Xochimilco & Fluvic Terric Anthrosol (Alcalic) \\
\hline 3 & San Luís Tlaxialtemalco & Episalic Fluvic Terric Anthrosol (Hyposidic, Alcalic, Thaptohistic) \\
\hline 4 & San Luís Tlaxialtemalco & Episalic Fluvic Terric Anthrosol (Hyposodic) \\
\hline 5 & San Luís Tlaxialtemalco & Episalic Fluvic Terric Anthrosol (Hyposodic, Clayic) \\
\hline 6 & Tláhuac & Fluvic Terric Anthrosol (Hyposodic, Thaptohistic) \\
\hline 7 & Tláhuac & Fluvic Terric Anthrosol (Sodic, Alcalic, Clayic) \\
\hline 8 & Tláhuac & Fluvic Terric Anthrosol (Sodic, Alcalic, Endoclayic) \\
\hline 9 & Míxquic & Episalic Fluvic Terric Anthrosol (Hyposodic, Alcalic, Endoclayic) \\
\hline 10 & Míxquic & Episalic Fluvic Terric Anthrosol (Sodic, Endoclayic, Bathihistic) \\
\hline
\end{tabular}




\section{Salinization and alkalinization hazards}

The soils of chinampas are both a cultural heritage and still a source of income for a significant part of population of Mexico City (Rojas-Rebela 1983). The traditional management practices showed their effectiveness for ages, and are believed to be the best option for actual agriculture in the region (Rojas-Rebela 1990). However, chinampas recently faced new challenges due to soil degradation issues, especially soil salinization, that require new approaches to soil management and conservation.

The soils studied here show a significant variation in salinity and sodicity. The reasons for the difference in soluble salts content is not well understood yet (Ramos et al. 2001; Sánchez et al. 2003). There is no dependence of salinity on clay or organic matter content (Figures 3, 4 and 6). Neither the accumulation of soluble salts in topsoil layers depends on the depth to groundwater level that corresponds to the total depth of profiles (the pits were excavated exactly down to the groundwater table). The most probable explanation for the irregular spatial pattern of salts accumulation is the proximity of uplifted areas, for example, of the volcano Xico that is situated close to Míxquic, the most salt-affected site. It explains why the Xochimilco site, which is strongly contaminated with urban waste, has the lowest soil salinity level. The uplifted volcanic bodies give an additional source of released cations to soils, while Xochimilco receives little input due to its remoteness from uplifted areas.

Most of the studied soils are characterized both by high salts content in surficial layer and alkaline reaction. A combination of salinity and alkalinity often means that the soil is affected by sodium carbonates that are regarded as very toxic salts. However, it is not the case for chinampas soils. The data on the ionic composition of soluble salts show that the most abundant salts in the studied soils are sodium and magnesium sulphates and chlorides. The alkaline reaction of the soils results from the effect of exchangeable sodium. Alkaline reaction caused by exchangeable sodium also has a negative effect on plant growth, but it is much less dangerous than the presence of sodium carbonates (US Salinity Laboratory Staff 1954; Sánchez et al. 2003). The data obtained for metropolitan soils differ from that reported for ex-Texcoco lake, where sodium carbonate is a common component (Sánchez et al. 2003). The ionic composition of salts is closely connected with the composition of volcanic ash that constitutes the major part of the lacustrine sediments (Bradbury 1971). The ash is initially rich in sodium and magnesium; also the abundance of sulphates is due to the high percentage of sulphur compounds in pyroclastic sediments.

The vertical distribution of soluble salts in most of the studied soils shows distinct accumulation at the surface (Figure 6); in some places one can see even morphologically evident salt accumulations in the topsoil. This type of vertical distribution is usually observed in the dry season, whilst in the rainy season the maximum of salt concentration moves to the deeper horizons (Huez et al. 1989). However, even periodical increase in soluble salts concentration in the topsoil may have a negative effect on soil productivity. Generally, increasing salinization has been reported repeatedly for chinampas soils for more than a half of a century (West and Armillas 1950; Coe 1964; Escurra 1990; Rojas-Rabiela 1983; Vallejo and Aguilera 1994; Jiménez et al. 1995; Ramos et al. 2001). The authors agree that the main reasons for salts accumulation are: water evaporation in channels that leads to gradual lowering of the water level, increasing urban waste disposal, illegal settlement and conversion of agricultural lands into urban areas. Complex driving forces of salinization require acomplex set of measures for soil protection and conservation. Simple measures like washing the salts would not work because highly mineralized water works as a source of salts (Huez et al. 1989). Also the salinity hazards should be treated together with other soil degradation phenomena, such as contamination with heavy metals and organic pollutants (Vallejo and Aguilera 1994; Gutiérrez et al. 1995; Ramos et al. 2001). For successful restoration of chinampas a combined approach should be applied, including soil remediation, water treatment and ecosystems protection. 


\section{Conclusions}

The soils of chinampas are unique products of a combination of lacustrine sedimentation under strong influence of pyroclastic materials, artificial soil construction, and long-term intensive agricultural management. These soils are characterized by layered structure, relatively uniform black and dark grey colour, irregular distribution of organic carbon and clay with depth, generally high percentage of carbon, including organic materials in some layers. Some soils show an increase in organic matter with depth, and other profiles have maximum organic matter content in the surficial layers and in the subsoil. We concluded that generally the dynamics of sedimentation resulted in the decrease in organic matter in the upper layers of lacustrine sediments, because of recent increase in erosion rates and consequent increase in the proportion of mineral particles in the sediments. Most probably high organic matter content in surficial layers of the second group of soils studied is due to excavation and accumulation of organic-rich subsoil material in the course of digging the channels. The vertical structure of the profiles is a result of management practices and sedimentation dynamics rather than pedogenetic differentiation of soil into horizons. These soils are classified as Fluvic Terric Anthrosols and vary in the presence of organic layers, salinity, and alkalinity.

The chinampas soils are characterized by alkaline reaction and high exchangeable sodium content. The alkalinity of soils depends more on exchangeable sodium than on free sodium bicarbonate; the dominant salts are sodium and magnesium sulphates and chlorides. Soluble salts content varies in a wide range and depends on the proximity to uplifted areas that serve as sources of freshly released ions. During the dry season we observed strong concentration of salts in the surficial layers of the majority of soils. Soil remediation in chinampas is a big challenge because a combined treatment of water, soil and vegetation is needed.

\section{Acknowledgements}

The research was supported by the National Counsel of Science and Technology of Mexico (CONACyT) grant No. 30712. The authors wish to acknowledge our colleagues in the Laboratory of Edaphology, Faculty of Sciences, National Autonomous University of Mexico (UNAM), who contributed to this research or supported the authors at various stages of the work. 


\section{REFERENCES}

- Birkeland PW. 1999. Soils and Geomorphology. New York, Oxford University Press, 3rd edition.

- Bradbury JP. 1971. Paleolimnology of lake Texcoco, Mexico. Evidence from diatoms. Limnology and Oceanography 16:180-200.

- Burt R, editor. 2004. Soil Survey Laboratory Methods Manual. Soil Survey Investigations Report No. 42 Version 4.0.USDA-NRCS, Lincoln, Nebr. http://soils. usda.gov/technical//mm/

- CETENAL. 1970. Modificaciones al Sistema de Clasificación FAO/UNESCO 1968, una opción ante el problema de clasificación de suelos para México. México, D.F.

- Coe DM. 1964. The chinampas of Mexico. Scientific American 260:90-96.

- De Cserna Z, de la Fuente DM, Palacios NM, Triay L, Mitre SLM, Mota PR. 1988. Estructura geológica, gravimétrica, sismicidad y relaciones neotectónicas regionales de la Cuenca de México. Boletín del Instituto de Geología 104:1-71.

- Ezcurra E. 1990. De las Chinampas a la Megalópolis. El Medio Ambiente en la Cuenca de México. Fondo de Cultura Económica, México. D.F.

- García E. 1973. Modificaciones al sistema de clasificación climática de Köppen. Offset Larios. México. D.F.

- García CN, Galicia PS, Aguilera HN, Reyes OL. 1994. Organic matter and humic substances contents in chinampa soils from Xochimilco-Tláhuac areas (Mexico). In: Proceedings of the 15th World Congress of Soil Science; 1994 July 10-16; Acapulco, Mexico; vol. 3: Symposium ID-12. p. 368-383.

- Gómez-Pompa, A. 1978. An old answer to the future. Mazingira 5:51-55.

- González-Salgado ME, García-Calderón NE, Almendros G. 2010. Características estructurales de ácidos húmicos y su efecto en el cultivo de Tagetes erecta L. en un suelo afectado por sales. Terra Latinoamericana 28:27-33.

- Gutiérrez RM, Siebe C, Sommer I. 1995. Effects of land application of wastewater from Mexico City on soil fertility and heavy metal accumulation: a bibliographical review. Environ Rev. 3:318-330.
- Heine K. 1987. Anthropogenic sedimentological changes during the Holocene in Mexico and Central America. In: Starkel L, editor. Anthropogenic sedimentological changes during the Holocene. Striae 26. p. 51-63.

- Huez MA, Ortega M, Ramírez C, Tone JL. 1989. Caracterización de algunas propiedades fisicoquímicas de los suelos y espesores subyacentes del predio Montecillo. Agrociencia 78:231-247.

- INEGI. 1997. Cuaderno Estadístico Delegacional. Xochimilco. INEGI, México.

- IUSS Working Group WRB. 2006. World Reference Base for Soil Resources. Soil Resources Report No. 103. FAO. Rome.

- Jackson ML. 1969. Soil chemical analysis - advanced course. Madison, Wisconsin, USA.

- Jiménez JJ, Rojas RT, del Amo S, Gomez-Pompa A. 1995. Conclusiones y recomendaciones del taller. In: Rojas RT, editor. Presente, Pasado y Futuro de las Chinampas. CIESAS, Patronato del Parque Ecológico de Xochimilco. México. D.F. p. 18-52.

- Lot A, Novelo A, Quiroz A. 1979. The chinampa: An agricultural system that uses aquatic plants. J. Aquat. Plant Manag. 17:174-175.

- Munsell Soil Color Charts. 2000. Revised washable edition. New Windsor, NY: Gretag Macbeth.

- Ramos BR, Cajuste JL, Flores RD, García CNE. 2001. Heavy metals, salts and sodium in chinampa soilsin México. Agrociencia 35:385-395.

- Van Reeuwijk LP, editor. 2002. Procedures for soil analysis, 6th edition. ISRIC-FAO. ISRIC Technical Paper No. 9.

- Reyes-Ortigoza AL, García-Calderón NE. 2004. Evolución de las fracciones húmicas de suelos en la zona chinampera de la Ciudad de México. Terra Latinomericana 22:289-298.

- Rojas-Rabiela T. 1983. Agricultura chinampera. Compilación histórica. Cuadernos universitarios. Serie agronomía 7. UACH, Mexico. p. 181-211.

- Rojas-Rabiela T. 1990. Chinampas un legado. Rev. México Indígena 6:42-45. 
- Rosas IB, Baez A, Coutiño M. 1984. Bacteriological quality of crops irrigated with wastewater in the Xochimilco plots, México City, México. Appl. Environ. Microbiology 5:1074-1079.

- Sánchez B, Ortega M, González V, Ruelas A, Kohashi S, García N. 2003. Tolerancia de tubérculos de papa cv. Alpha en etapa de brotación a condiciones de salinidad. Terra 21:481-491.

- Schoeneberger PJ, Wysocki DA, Benham EC, BrodersonWD, editors. 2002. Field book for describing and sampling soils, Version 2.0. NRCS, NSSC, Lincoln, NE.

- Sedov S, Solleiro-Rebolledo E, Morales-Puente P, Arias-Herrera A, Vallejo-Gómez E, Jasso-Castañeda C. 2003. Mineral and organic components of the buried paleosols of the Nevado de Toluca, Central Mexico as indicators of paleoenvironments and soil evolution. Quatern. Intern. 106-107:169-184.

- Tan KH. 1996. Soil sampling, preparation, and analysis. NY: Marcel Dekker, Inc.

- Targulian VO, Krasilnikov PV. 2007. Soil system and pedogenic processes: Self-organization, time scales, and environmental significance. Catena 71:373-381.

- US Salinity Laboratory Staff. 1954. Determination of the properties of saline and alkali soils. In: Richards LA, editor. Chapter 2. Diagnosis and improvement of saline and alkali soils. Agriculture Handbook No. 60 . USDA-ARS. p. 7-33.

- Vallejo AC, Aguilera N. 1994. Diagnóstico de los índices de contaminación de algunas calicatas de Suelos de Chinampa de San Gregorio Atlapulco, D.F. In: Llerena VFA., Hernández FL, Jacobo TC, Sánchez BB, editors. III Reunión Nacional de Halófitas y Manejo de Aguas y Suelos Salinos, SARH y Comisión Nacional del Agua. México. D.F.p. 114-122.

- West RC, Armillas P. 1950. Las chinampas de México. Poesía y realidad de los jardines flotantes. Cuadernos Americanos 9:165-182. 